\title{
XIII.-Description of a new species of water- bird from Cochin China belonging to the genus Porphyrio
}

\section{D.G. Elliot F.R.S.E.}

To cite this article: D.G. Elliot F.R.S.E. (1878) XIII._Description of a new species of water-bird from Cochin China belonging to the genus Porphyrio, Annals and Magazine of Natural History, 1:1, 98-99, DOI: 10.1080/00222937808682295

To link to this article: http://dx.doi.org/10.1080/00222937808682295

曲 Published online: 15 Oct 2009.

Submit your article to this journal $\llbracket$

Џلll Article views: 1

Q View related articles $\sqsubset$ 


\section{Plate VIII.}

Fig. 1. Top view of the skull of the male Solitaire.

Fig. 2. Under view of the skull of the female Solitaire.

Both figuree are of the natural size.

XIII.-Description of a new Species of Water-bird from Cochin China belonging to the Genus Porphyrio. By D. G. EllioT, F.R.S.E. \&c.

\section{Porphyrio Edwardsi.}

Adult. Ear-coverts, lores, and round the eyes greyish white. Back of head brown, darkest in the centre, where it is almost a brownish black with a purple tinge, shading off to a greyish white towards the frontal plate and the sides of the head. Cheeks bluish white. Chin and throat brownish, with a bluish shade. Back and sides of neck, lower part of breast, and flanks dark violet-blue. Front of neck and upper part of breast, shoulders, and under wing-coverts deep turquoise-blue. Back, rump, wings, secondaries, primaries, and tail uniform greenish black. Middle of abdomen and crissum brownish black. Under tail-coverts pure white. Bill, frontal plate, legs, and feet apparently bright red. Total length $16 \frac{1}{4}$ inches, wing $10 \frac{3}{4}$, tail $4 \frac{1}{4}$, bill along gape $1 \frac{1}{4}$, width of frontal plate at posterior margin $\frac{7}{8}$, tarsus $3 \frac{3}{8}$, middle toe $3 \frac{3}{4}$, claw $\frac{3}{4}$.

Young. Top and back of head covered with downy black feathers; sides of head grey; chin and throat white; breast dark turqoise-blue, flanks and abdomen violet-blue. Crissum and thighs brownish black, streaked in certain places with white. Wings and back greenish black. Rump brownish black. Bill red, with the culmen and lengthened spots on the mandibles near the commissure black. Frontal plate small, apparently red. Legs and feet pale red. Total length $10 \frac{1}{2}$ inches, tarsus $2 \frac{3}{4}$, bill at gape 1 .

Hab. Cochin China; Saigon (Germain); Bangkok (Bocourt).

Four specimens of this fine species are in the collection of the Paris Museum, three adults and one young bird, obtained in different localities in Cochin China. It has probably been confounded with the P. poliocephalus, Lath., of India, which it resembles in certain portions of its plumage. The present species differs in being darker on the back of the head, in having the blue of the breast of a darker shade, and especially in having the upper parts, including the entire wings, greenish black, instead of the purple back and rump and pale greenish blue wings of $P$. poliocephalus. This colouring of the upper 
parts is so conspicuously different in the two species, that either one can be recognized at a glance. Two of the adult specimens are precisely alike; the third is a little paler upon the sides of the head; but all possess the uniform greenish black back and wings.

It gives me great pleasure to bestow upon so handsome a bird the name of my friend Professor Alphonse MilneEdwards, so well and favourably known for his many and highly important contributions to natural science, and who, in the kindest manner, has placed at my disposal all the specimens of this genus contained in the collection of the museum to assist me in my investigation of the group.

\section{BIBLTOGRAPHICAL NOTICE.}

The American Palcozoic Fossits, \&c. By S. A. Mrtubr. Large 8vo. Pp. 253. Published by the Author : Cincinnati, U. S., 1877.

THIs work consists of a catalogue of the genera and species of Palæozoic Fossils found in North America, giving the names of authors, dates, places of publication, groups of rocks in which the fossils oceur, and the etymology and signification of the words, together with a preliminary discourse, by Prof. E. W. Claypole, on the construction of systematic names in palæontology, and an Introduction by the author, on the stratigraphical geology of the American Palæozoic rocks.

This, we believe, is the latest of many useful catalogues of fossils prepared by geologists of different countries, and devoted to the consideration of either particular groups or the world-wide distribution of organic remains. In this case the fossils treated of are limited to those of the Palæozoic Rocks of North America, and form an extensive list of at least 1000 genera and 8000 species, besides very many names (upwards of 2000) which are either synonyms or not well determined.

The organie remains here enumerated are grouped according to their Orders, the Families of which are mentioned for each division.

A special feature in this work is a most praiseworthy attempt to produce the names with correct etymology and derivation. But besides those errors mentioned in the lists of corrigenda at pages 64 and 246, there are many that have escaped the author's notice; and some of them go to prove how true his observation is that the mistake of the original name of a species is perpetuated in successive transcripts; whilst others show, as usual, the difficulty found by any one in trying to express himself in a language unknown to him.

Prof. Claypole, both in his excellent essay on nomenclature and in revising a great portion of the Catalogue, has evidently worked 